\title{
A systematic review of research on climate change adaptation policy and practice in Africa and South Asia deltas
}

\author{
Shuaib Lwasa
}

Received: 9 September 2013/Accepted: 15 October 2014/Published online: 12 November 2014

(C) The Author(s) 2014. This article is published with open access at Springerlink.com

\begin{abstract}
Recent years have witnessed a rapid increase in scholarship on adaptation to climate change. Peer-reviewed literature, governmental communiqués and reports are increasingly reporting formulated and implemented climate change adaptation policies, strategies and plans of action. A large part of this literature describes general policy strategies, while there is limited published work on adaptation interventions at the local scale. The generality of adaptation is not only limited to strategies but also in terms of coverage of regions believed to be highly vulnerable to the effects of climate change. Among such climate change "hotspots" where understanding on adaptation is limited are river deltas. Herein, this paper synthesizes selected literature on adaptation policy and practice in river deltas located in Africa and South Asia. A systematic review methodology was used to scan online knowledge portals for published papers and also unpublished government documents. The review characterizes the state of adaptation policy in African and South Asian deltas and identifies future research priorities targeting climate change adaptation in large delta regions.
\end{abstract}

Keywords Adaptation policy - Climate change - Deltas . Vulnerability $\cdot$ Africa $\cdot$ South Asia $\cdot$ Systematic review

S. Lwasa $(\bowtie)$

Department of Geography, Geo-informatics and Climatic Sciences, School of Forestry, Environmental and Geographical Sciences, CAES, Makerere University, P.O. Box 7062, Arts Building, East Wing Ground Floor Room 12, Kampala, Uganda e-mail: shuaiblwasa@gmail.com; lwasa_s@caes.mak.ac.ug

\section{Introduction}

Low-elevation coastal zones of densely populated river deltas are experiencing loss and damage to infrastructure and livelihoods from climate-induced risks of flooding, storm surges, salinization of fresh water and loss of biodiversity (Woodworth et al. 2007; Aromar 2008; Wassmann et al. 2009; Hinkel et al. 2012; Kilroy (2014); Rabbani et al. 2013; IPCC 2014b). Critical infrastructure and social systems in these deltas have experienced considerable damage, and these risks are projected to increase with future climate change (Nishat et al. 2013; ISSC, UNESCO 2013). National-, subregional- and local-level interventions have long been implemented to address natural disasters, but the increasing frequency and intensity of extreme weather events are posing heightened threat to river deltas. Thus, adaptation strategies are already beginning to emerge for known and anticipated long-term impacts of climate change with a mix of planned and spontaneous interventions that involve multiple actors (Anbumozhi et al. 2012; IPCC 2014b). For example, national adaptation plans have been formulated and the United Nations Framework Convention on Climate Change (UNFCCC) National Adaptation Plans of Actions (NAPA) repository indicates efforts are being made to design and implement adaptation strategies in key sectors prioritized of Health, Biodiversity, Tourism and Agriculture by National Adaptation Programs of Action (NAPAs) in countries including Bangladesh, Nigeria, Senegal and India (Moors et al. 2011).

It is also recognized that current adaptation action is insufficient in light of projected increase in vulnerabilities to climate change (Ole et al. 2009; Bunce et al. 2010), with large data gaps evident on the state of adaptation planning in river deltas of selected hotspot countries of Africa and 
South Asia covered in this special edition (De Souza et al. this issue; Ford et al. this issue). The adaptation gaps limit the understanding and ability to evaluate the preparedness of nations with large river deltas to deal with projected future climate change impacts and to monitor adaptation progress over time. In response, this paper reviews selected literature on adaptation policy and practice in river deltas of Africa and South Asia. The literature review covers 11 deltas from Africa and five deltas of four South Asian countries (Pakistan, India, Nepal and Bangladesh), following the focus of the special edition (De Souza et al. this issue). The main objective is to assess planned adaptation policy and practice to synthesize emerging issues relevant for research and policy development. The paper identifies what is known about current adaptation policy and practice and what needs to be known for future adaptation policy (Ford et al. 2011).

\section{Methods}

\section{Conceptual framework}

Various frameworks have been developed for climate vulnerability and adaptation assessment, leading to an emergence of climate adaptation policy. The emergence of adaptation policy in low-income nations, for example, is partly related to the recommendations of the UNFCCC for incorporate adaptation into national agendas by developing country member states (UNFCCC 2007). The adaptation framework utilized in this systematic review is that developed by Eisenack and Stecker (2012) and is adopted because of its explicit representation of actors, actions and processes that explain the critical elements of adaptation policy formulation and implementation. This framework conceptualizes adaptation policy as a "response" to climate change impacts. The response to the impacts is framed as adaptation activities involving the receptor, exposure unit and operator of such activity. Knowledge, power and resources mediate the set of adaptation activities. According to this framework, the outcome of interactions between the actors and the resources is policy practice, which can occur at multiple scales. The adaptation framework proposed by Eisenack and Stecker 2012 guided the selection of elements necessary for the review of policy and practice in deltas selected here. Building on the understanding from the framework, two adaptation policy perspectives guide the review. The first is planned adaptation policy targeting climate change risks (Haasnoot et al. 2013; Hugo 2013). Several countries with deltas have conducted risk assessments and formulated strategies and plans for adaptation at various scales (IPCC 2014a). But adaptation policy is still in the form of broad strategies at the national level through NAPAs and National Communications (NC). The NAPAs and NCs are, however, currently under review in some of the countries included in this study (Saito 2013). The second perspective on policy response is the general development agenda, which may inherently have adaptation strategies (Bunce et al. 2010). This includes development actions that have long been implemented and or planned in the deltas around infrastructure installation, ecosystem restoration and protective measures against climate-related risks such as storm surges, sea level rise (El-Raey 1997; Sarwar and Khan 2007; Fuchs 2010). Based on this analytical framework, policy strengths and gaps are assessed in the context of adaptation plans. Policy gaps are conceptualized first as an absence of adaptation-targeted policy, and secondly as missing elements in existing policy that may be required to augment adaptation practice. The policy gaps are also understood as deficiencies in knowledge, resources and power across a range of actors including institutions responsible for mainstreaming adaptation.

\section{Systematic review approach}

This paper employs a systematic review methodology following Berrang-Ford et al. (this issue) and De Souza et al. (this issue), through a stepwise process of selecting the literature sources that are subjected to specific questions. The review focuses on work published after the publication of the Intergovernmental Panel on Climate Change 4th Assessment Report (IPCC AR4) (2007) and uses both peer-reviewed and gray literature. Gray literature is included because several of the river deltas do not have representation in peer-reviewed literature, yet there are some published policy documents concerning adaptation in these regions. These documents include official UNFCCC NCs and NAPAs, evaluation documents, project documents and non-published theses. Evidence was then sought from the literature about the planning and implementation of adaptation policies, with adaptations evaluated based on their successes and/or shortcomings in particular contexts and settings. This formal review process is coupled with targeted interviews conducted with adaptation practitioners in the selected river deltas being assessed.

The approach to the review involved selection, coding, analysis and content review of the literature sources. The first step in the systematic review was to search electronic databases using ScienceDirect and Web of Knowledge catalogues for peer-reviewed literature. Inclusion and exclusion criteria were formulated to guide the search of the literature. The inclusion key terms were "climate change" and "deltas" or "vulnerability" or "adaptation" and "policy." This yielded 1,689 records and a search within the results was conducted with key terms of 
Table 1 Major variables against which the literature sources were analyzed

\begin{tabular}{|c|c|c|c|c|c|c|}
\hline Variable & Delta of focus & Scale of study & $\begin{array}{l}\text { Country } \\
\text { of focus }\end{array}$ & Type of study & Methods & Thematic focus \\
\hline $\begin{array}{l}\text { Values in } \\
\text { matrix }\end{array}$ & $\begin{array}{l}\text { Ganges-Brahmaputra, } \\
\text { Nile, Okavango, Indus, } \\
\text { Niger, Senegal, Sine } \\
\text { Saloum }\end{array}$ & $\begin{array}{l}\text { Delta, national, river } \\
\text { basin }{ }^{*}, \text { international, } \\
\text { regional, Africa, } \\
\text { south Asia }\end{array}$ & $\begin{array}{l}\text { All } \\
\text { possible } \\
\text { delta } \\
\text { countries }\end{array}$ & $\begin{array}{l}\text { Conceptual, policy } \\
\text { analysis, } \\
\text { adaptation, } \\
\text { impact } \\
\text { assessment }\end{array}$ & $\begin{array}{l}\text { Qualitative, } \\
\text { Quantitative, } \\
\text { Mixed } \\
\text { methods } \\
\text { Consultation } \\
\text { Review }\end{array}$ & $\begin{array}{l}\text { Vulnerability, } \\
\text { Adaptation, } \\
\text { development, } \\
\text { adaptation policy, } \\
\text { delta profiles } \\
\text { Adaptation financing } \\
\text { Adaptation planning } \\
\text { Impact studies }\end{array}$ \\
\hline
\end{tabular}

* Excluded for South Asia

Italic entries are the variables on basis of which lieterature sources/papers were assessed and quantified

"Africa" and/or "South Asia" OR "deltas" reducing the records to 346. The exclusion criterion was the cut-off year of 2006. This was followed by checking all the records to remove duplicates. Although papers with a geographic focus beyond deltas such as river basins or catchments in South Asia were excluded from this list, a few river basinfocused papers in Africa were included due to limited literature on river deltas in Africa. With removal of duplicates and an initial review of abstracts, a total of 41 peerreviewed articles were selected for final inclusion in the assessment. In addition, a total of 44 gray literature documents were selected, making 85 documents to review in total, four of which had unknown dates of publication.

The selected papers were coded according to a set of questions and possible responses in a matrix. The basic variables on the basis of which the data was coded in the matrix included publication type, date, country and authors, as indicated in Table 1. Content of the papers was extensively reviewed to discern the evidence and agreement about climate change adaptation-targeted policy and practice. Adaptation policy in this paper includes the policy formulations, strategies and plans to achieve climate change-targeted adaptation, while adaptation practice are the day to day actions and investments responding to climate risks. Evidence is measured as the extent to which the literature source show existence of adaptation policy and implementation, while agreement is the extent to which literature sources agree or not on specific issues of practice, financing in policy context. The extensive review was conducted to identify the implementation of adaptation policies as well as policy gaps. Papers were also reviewed to assess lessons from adaptation interventions. The systematic review also included other materials from websites and online databases. Several websites for projects, international or regional networks and agencies were accessed. Five national communications were also reviewed from India, Bangladesh, Nigeria, Egypt and Pakistan. A total of 10 NAPAs relevant to the regional focus of the study were reviewed accessed from the UNFCCC repository database.
These sources provided sources of information on risk assessment, planned adaptation as well as progress in implementation of adaptation policy in the respective countries.

Because some deltas are under-represented in the literature, a small number of interviews were also conducted to scope the state of adaptation planning and action, if any, in these locations. The interviewees were selected on the basis of availability and willingness to participate in the interview. A scientist from Okavango Research Institute was interviewed on January 18 2013, a disaster risk reduction program manager of the Islamic Relief Bangladesh was interviewed on 13 June 2013, and an official from Niger Delta Development Commission was interviewed on August 6 2013. The interviews were utilized to elicit additional data on adaptation planning and practice in the respective deltas.

\section{Climate change vulnerabilities and impacts on deltas}

Two other papers in this special edition have relevance to this study on river deltas: One documents projected biophysical impacts of climate change in "hotspot countries" (Kilroy 2014), while the social vulnerability paper focuses on determinants of vulnerability (Tucker et al. this issue). The biophysical paper indicates that there is limited literature focused on deltas but identifies key potential climate change impacts. In all the deltas covered in the review, for example, sea level rise is predicted at various rates of 64-104 mm per annum in Africa (Hinkel et al. 2012; Ministry of Energy and Forestry 2008) and 0.5-150 mm per year in South Asia this century (Sarwar and Khan 2007; Syvitski et al. 2009). Further, IPCC AR5 reports that sea level changes, ocean temperatures and ocean acidity are the key biophysical risks affecting coastal areas (IPCC 2014b). These risks are reported with very high confidence and high agreement, and potential impacts on deltas range from saline water intrusion, storm surges, coastal erosion and biodiversity loss, which have secondary effects on 
infrastructure, coastal resources, social systems and urban systems (IPCC 2014b). Delta flooding is also associated with extreme weather events of excessive and/or intense precipitation in the associated river catchments (Syvitski et al. 2009; Olobaniyi and Owoyemi 2010). In 2011 and 2012, for example, there was widespread flooding in the Niger delta associated with upstream river discharge changes (Ezekiel et al. 2013; Ghile et al. 2014). Besides the impacts of climate variability and extreme events documented, trajectories of climate change impacts point to a potentially severe but uncertain future (Ford et al. 2011; Anbumozhi et al. 2012; IPCC 2014a).

With high population densities in river deltas, the social impacts are predicted by the scientific community to be medium to severe, but prioritization for policy seems to rank such impacts as a medium to low priority (Tucker et al. this issue; Kilroy 2014; ISSC, UNESCO 2013). The disconnect between impact assessments and policy priorities is the basis of policy gap analysis in this paper. The differences in vulnerability between and within deltas are also important in determining the adaptation response (Sharma and Hugo 2010a; Brauch 2012; Moors et al. 2011). Institutional challenges, for example, will play a role in determining vulnerabilities and policy practice and differ widely across delta nations (Lebel et al. 2013). The incongruence between national-level policies and locallevel adaptation action is echoed in various studies as an important issue with short- and long-term implications on planned adaptation (Hyder et al. 2010; Lee and van de Meene 2012; Rao 2013). National and sub-national planning on the one hand and community-based adaptation on another tend to differ, with the former not adequate in addressing the social, environmental and institutional drivers of vulnerability (Bunce et al. 2010), while locallevel adaptations have been reported as incremental with limited potential for up-scaling (Kates et al. 2012). As a result, climate change policy and practice seems to take two related but differentiated routes of sector-based adaptation and community-based adaptation, though the potential for integration is yet to be explored (Lebel et al. 2013).

\section{Results}

The review indicates an increase in published papers focused on adaptation planning and practice in African and South Asian deltas from 1 to 4 between 2006 and 2013. Fifty-two percent of all papers reviewed were from the gray literature $(n=85)$, and $48 \%$ are peer-reviewed. The Ganges-Brahmaputra and Niger deltas are represented in $25 \%$ of papers reviewed. The literature on African deltas is largely in the gray literature (66\%) compared with $50 \%$ $(n=44)$ for South Asia. Results show that $32 \%$ of the selected literature focused on impact assessment, $19 \%$ on policy analysis and $15 \%$ on adaptation planning as the study scope. The high representation of impact studies is possibly related to the IPCC Fourth Assessment Report (AR4) findings and climate change impacts narrative, which may have motivated a proliferation of impacts studies.

With regard to adaptation strategies and policy analysis, most literature was focused at the national $(23 \%)$ and subregional levels $(25 \%)$. This evidence correlates with the interviews conducted with key informants, in which the focus on policy is at the river basin or subregional scale within the delta countries. For example, in Niger, the master plan covers all the nine states in the Niger delta, while the Ganges-Brahmaputra has a regional coastal zone management strategy. Other deltas where adaptation planning and/or development are reported at subregional scale include the Zambezi, Orange River, Pungue and Irrawaddy. A small proportion of the literature (1.2\%) was characterized as development oriented and focuses on coastal zones. This evidence relates to long-term development interventions in the coastal areas as a response to disasters and restoration of coastal ecosystems.

The thematic focus of the literature reviewed shows $31 \%$ focused on adaptation policy, $20 \%$ on adaptation practice, $34 \%$ on vulnerabilities and $8 \%$ on adaptation planning (Table 1). There is little evidence of adaptation financing being reported on, noted in only $1 \%$ of the literature reviewed here. The interpretation of these findings points to a high level of conceptualization of adaptation policy but with limited reporting on financing and implementation in the deltas. This apparent limited evidence of reported implementation and financing may be related to the "actors" involved in adaptation implementation, the majority of whom in low- and middle-income nations are NGOs and communities that often do not publish on adaptation activities. Moreover, since most of the literature reviewed was gray literature, the national documentation, strategies and policies usually do not include detailed financing but only give indicative figures of the overall plan. For example, none of the Integrated Coastal Zone Management Strategies of Bangladesh, the Niger Delta Master Plan of Nigeria and the Country profile of Climate Risk and Disaster Risk Reduction of Senegal have an itemized budget for targeted adaptation.

With respect to methodologies, $34 \%$ of the reviewed papers are based on qualitative methods, while $31 \%$ are based on a combination of quantitative and qualitative methods. The results suggest that adaptation planning is at conceptual level for strategy formulation but with limited implementation of policy, which explains the limited knowledge on adaptation practice in the deltas. However, 


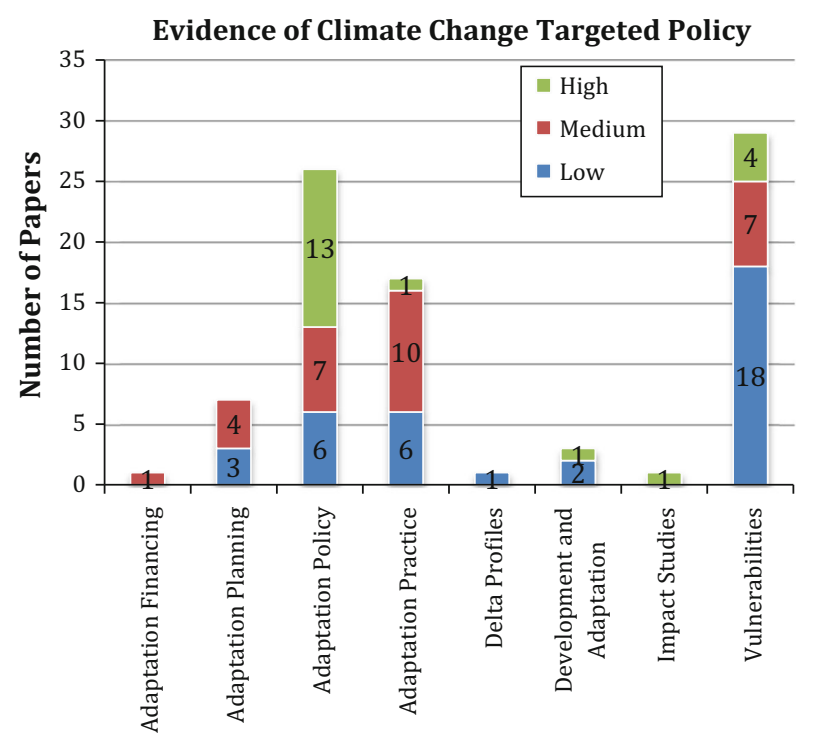

Fig. 1 Evidence of climate change-targeted policy

although research and knowledge generation efforts are underway on adaptation policy and practice, the limited knowledge may be due to time lag between knowledge generation and publication. The dominance of GangesBrahmaputra and Niger delta in the literature may be influenced by the magnitude of the population at risk, development and resource endowments in the two deltas.

Selected literature was also analyzed vis-à-vis existing policy. Figure 1 indicates that vulnerability assessments are more common than climate-targeted policies. Evidence on adaptation practice is assessed as medium with some papers focused on both development and adaptation indicating anticipatory adaptation policy and planning (Eadson 2011). Vulnerability-focused papers also report coping mechanisms at various levels, while adaptation policyfocused papers report strategies that have been partly implemented (UNFCCC 2012). For example, the UNFCCC portal shows that countries such as Bangladesh have implemented several adaptation strategies, one of which is the community-based adaptation through coastal afforestation (Rawlani and Sovacool 2011). In addition, the Sine Saloum coastal mangrove forest restoration by Government of Senegal is also seen as an adaptation intervention. A review of some of the practices by development agencies reveals that there are interventions responding to disaster risk management and livelihoods at multiple scales. For example, in Zambezi, Okavango and Betsiboka deltas' interventions are at regional scale compared with community-level interventions in Ganges-Brahmaputra (Sharma and Hugo 2010a; Speranza 2010; Adekola and Mitchell 2011a; Motsholapheko et al. 2011). Adaptation interventions in many deltas are still at regional scale and at conceptual level.

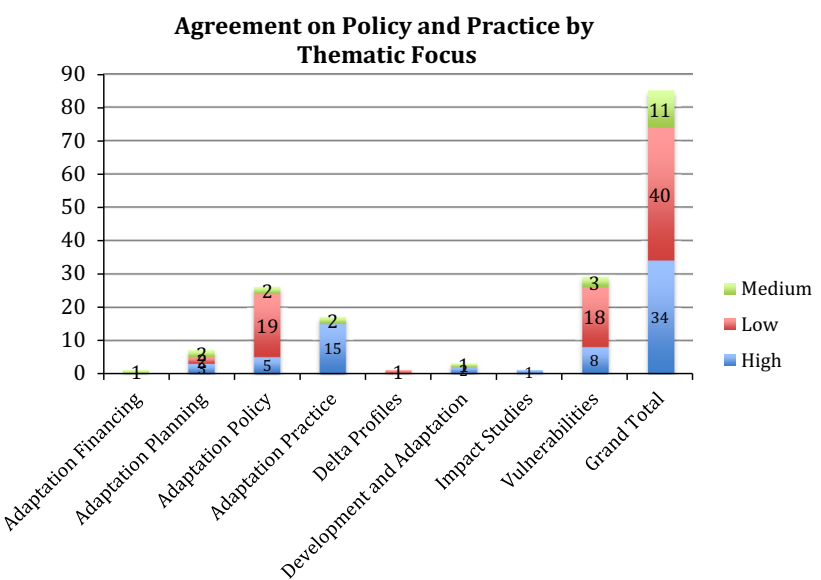

Fig. 2 Agreement in papers about existing policy and practice by thematic focus

Further analysis was conducted to assess whether the reviewed papers agree on policy and practice in the deltas. Agreement in this context is a measure of whether papers converge on policy practice in deltas. As indicated in Fig. 2 below, there is low agreement on papers focused on adaptation practice compared with medium agreement on vulnerability-focused papers. Although evidence on adaptation practice exists, there is low agreement on whether it is climate adaptation targeted. This is because the literature sources are largely focusing on anticipated climate risks and can hardly relate to experienced risks due to challenge of attribution of experienced risks to climate change. The medium agreement on vulnerability is also due to the same challenge of attributing extreme events to climate change (Cameron et al. 2011; Smith et al. 2000). In addition, the medium agreement on vulnerability can be explained by microscale interventions at community level related to international initiatives (Fünfgeld et al. 2012); there is little evidence that these initiatives are responses to particular climate risks.

\section{Discussion}

Adaptation policy and planning in delta regions is dominated by national-level initiatives in NAPA's, sectoral reports and development plans (Asian Development Bank 2009; Hyder et al. 2010; Islam 2006; Steve et al. 2008). Adaptation practice on the other hand is dominated by NGOs, both international and local, that interface with the communities affected by the impacts of extreme weather events (Steve et al. 2008; UNFCCC 2012). For example, the manager at Islamic Relief Bangladesh noted that the disaster risk reduction program involves microscale interventions related to education about cyclone-related disasters with a gender dimension focusing on people with 
disabilities and women. In the Niger delta, interviews revealed that projects at a community level involve agriculture-based livelihoods and fisheries to create opportunities for youth as an effort to draw them away from violence that has engulfed the delta region for decades. In general, the review shows that $31 \%$ of the literature is focused on adaptation policy and $20 \%$ on adaptation practice. Adaptation practice is predominantly bottom-up from household, community to regional levels (Steve et al. 2008), as is the case in Ganges-Brahmaputra, Okavango, Pungue, while in Niger, Krishna, Irrawaddy and Sine Saloum, such practice is from regional and national agencies. Two key features about adaptation practice are important to note, the first is the "learning by doing" strategy deployed by actors in the Ganges-Brahmaputra (Lee and van de Meene 2012). As mentioned by the manager at Islamic Relief Bangladesh, the NGOs are strongly involved in the community-based intervention through the principles of "learning by doing". At a subnational level, adaptation practice is largely driven by government agencies in response to anticipated risks (Haig 2010; Niger Delta Development Commission 2006), much of which is not properly documented or published. From restoration of mangrove forests, coastal erosion measures like sandbag barriers, storm surge barriers, ecosystem-based livelihoods to adaptation of housing to flooding, action is based on both experienced and anticipated risks (Kates et al. 2012). The practice at the microscale raises a major policy gap because uptake and up-scaling is reported to have many challenges (Allen 2006). As noted by the scientist interviewed in the Okavango, livelihood adjustment due to competition for pasture and water between livestock and wildlife in the delta has been initiated by NGOs but scaling up remains a big challenge. The pathways for scaling up are not well explored creating a situation of discrete adaptations that benefit some communities and not others. The limitation to microscale interventions has been widely critiqued as a driver for maladaptation or incremental adaptation when successful measures such as flood-resistant housing and livelihoods in Mozambique remain at microscale with limited impact at broader scale (Bhattacharya 2010; Black et al. 2011). Evidence shows that community-level adaptation responses have traditionally focused on disaster risk reduction, which is also a recent change from managing disasters (Allen 2006; Auld 2008). There is increasing recognition of post-disaster recovery strategies to reduce future risks (Gaillard and Mercer 2013; Pelling and Blackburn 2014). For example, in Mozambique and Bangladesh, both of which are affected by cyclone-induced flooding, flood-resilient housing has been implemented to minimize fatalities to transcend disaster response approach. Coupled with post-disaster recovery, reviewed literature provides the evidence of increasing anticipatory and planned adaptation (Fünfgeld et al. 2012; Rawlani and Sovacool 2011).

The underlying feature of contemporary disaster risk reduction is the enabling of communities to reclaim previous rights interrupted by a key disaster event (UNFCCC 2012), yet this has been critiqued in that such communities are positioned back in vulnerable situations and possibly hit by another disaster (Kates et al. 2012). An example is the frequency of storms and floods in river deltas with high magnitude, rebuilding infrastructure in deltas has only enabled communities to reclaim their rights but does not reduce vulnerability to future risks (Pelling and Blackburn 2014). The major challenge and policy gap is the lack of long-term adaptation planning that is transformational (Kates et al. 2012) in the sense that communities would be enabled to claim new rights such as land rights to settle in protected areas (Pelling and Blackburn 2014). But such long-term planning will require implementation that transcends incremental adaptation to address the systemic problems of policy interventions for reduced risks (Eisenack and Stecker 2012; Kates et al. 2012). Although a plausible approach to adaptation policy and practice, transformational adaptation has conceptual limitations regarding what to transform and issues about uncertainty of future climate risks. Adaptation planning for long-term periods may be unrealistic due to the dynamics of climate and social systems (Marcus 2010; Sharma and Hugo 2010a). The dynamic nature of policy-shaped vulnerabilities that continue to expose deltas and the populations to climate risks can also play against transformational adaptation.

Adaptation policy that targets climate risks in deltas of Africa and South Asia is assessed based on three perspectives. The first relates to adaptation-targeted policy at regional scale drawn on basis of anticipated climate impacts. The second is in relation to level of focus by the policy in relation to whether households, communities or regional agencies are entry points for action. The third is based on identifiable evidence about interventions. On the basis of these three perspectives, a synthesis of policy and practice is presented in the table below to show the state of knowledge on adaptation policy and practice. The matrix below summarizes all deltas included in the review against the existence of policy, geographic scale, degree of policy implementation, adaptation-planned action and policy gaps (Table 2).

Policy gaps are conceptualized as the nonexistence of adaptation-targeted policy on the one hand, and on the other, existence of adaptation-targeted policy but which may require adjustments based on emerging knowledge on risks (Berrang-Ford et al. 2011). However, climate change uncertainties make it difficult to anticipate the risks and therefore formulation of the adaptation policy 
Table 2 Adaptation policy and practice, issues and gaps

\begin{tabular}{|c|c|c|c|c|c|c|}
\hline \multirow[t]{2}{*}{ Delta } & \multirow{2}{*}{$\begin{array}{l}\text { Example of existing } \\
\text { generic policy }\end{array}$} & \multirow{2}{*}{$\begin{array}{l}\text { Geographic } \\
\text { scope }\end{array}$} & \multirow{2}{*}{$\begin{array}{l}\text { Thematic focus of } \\
\text { implementation }\end{array}$} & \multirow{2}{*}{$\begin{array}{l}\text { Actors in } \\
\text { adaptation }\end{array}$} & \multicolumn{2}{|l|}{ Policy gaps } \\
\hline & & & & & $\begin{array}{l}\text { Evidence of } \\
\text { existing } \\
\text { adaptation } \\
\text { policy** }\end{array}$ & $\begin{array}{l}\text { Policy for } \\
\text { enhancement }\end{array}$ \\
\hline Irrawaddy & Conservation & Delta wide & Not adaptation targeted & $\begin{array}{l}\text { State is major } \\
\text { actor }\end{array}$ & No evidence & $\begin{array}{l}\text { Adaptation-targeted } \\
\text { policy needed }\end{array}$ \\
\hline Indus & Conservation & $\begin{array}{l}\text { Community } \\
\text { and coastal } \\
\text { region }\end{array}$ & Not adaptation targeted & $\begin{array}{l}\text { Trans } \\
\text { boundary } \\
\text { agencies, } \\
\text { international }\end{array}$ & No evidence & $\begin{array}{l}\text { Build on ongoing } \\
\text { projects and } \\
\text { coastal } \\
\text { conservation } \\
\text { programs }\end{array}$ \\
\hline Krishna & $\begin{array}{l}\text { Evidence of intense } \\
\text { utilization but not } \\
\text { adaptation } \\
\text { targeted }\end{array}$ & $\begin{array}{l}\text { Delta, coastal } \\
\text { resource } \\
\text { utilization }\end{array}$ & $\begin{array}{l}\text { Conservation and land } \\
\text { use planning for } \\
\text { irrigation }\end{array}$ & $\begin{array}{l}\text { International, } \\
\text { state }\end{array}$ & No evidence & $\begin{array}{l}\text { Build on existing } \\
\text { projects related to } \\
\text { water resource use }\end{array}$ \\
\hline Mahanadi & Evidence exists & Community & $\begin{array}{l}\text { Wetland conservation } \\
\text { for livelihoods }\end{array}$ & $\begin{array}{l}\text { International } \\
\text { state, } \\
\text { communities }\end{array}$ & No evidence & $\begin{array}{l}\text { Adaptation-targeted } \\
\text { policy needed }\end{array}$ \\
\hline Nile & $\begin{array}{l}\text { Evidence } \\
\text { Mediterranean } \\
\text { integrates } \\
\text { assessment } \\
\text { framework }\end{array}$ & $\begin{array}{l}\text { Cities and } \\
\text { cultural areas }\end{array}$ & $\begin{array}{l}\text { Adaptation of urban } \\
\text { infrastructure, } \\
\text { agriculture and water } \\
\text { management }\end{array}$ & $\begin{array}{l}\text { International, } \\
\text { interstate or } \\
\text { local } \\
\text { authority }\end{array}$ & $\begin{array}{l}\text { Climate proofing } \\
\text { and land use } \\
\text { planning in } \\
\text { Alexandria }\end{array}$ & $\begin{array}{l}\text { Augment current } \\
\text { programs for } \\
\text { policy formulation }\end{array}$ \\
\hline Orange & ORASECOM & Regional & $\begin{array}{l}\text { Hydro-climatic } \\
\text { scenarios, catchment } \\
\text { management }\end{array}$ & $\begin{array}{l}\text { Interstate and } \\
\text { community } \\
\text { groups }\end{array}$ & $\begin{array}{l}\text { Catchment } \\
\text { management }\end{array}$ & $\begin{array}{l}\text { Expand on } \\
\text { catchment } \\
\text { management } \\
\text { program for policy }\end{array}$ \\
\hline Sine Saloum & $\begin{array}{l}\text { Evidence around } \\
\text { coastal mangrove } \\
\text { restoration }\end{array}$ & Estuary region & $\begin{array}{l}\text { Carbon financed } \\
\text { projects }\end{array}$ & $\begin{array}{l}\text { Communities, } \\
\text { state } \\
\text { international } \\
\text { agencies }\end{array}$ & $\begin{array}{l}\text { Mangrove } \\
\text { restoration and } \\
\text { livelihoods }\end{array}$ & $\begin{array}{l}\text { Expand CDM and } \\
\text { livelihood } \\
\text { activities to policy }\end{array}$ \\
\hline Zaire & Some evidence & Catchment & & & No evidence*** & $\begin{array}{l}\text { Adaptation-targeted } \\
\text { policy needed }\end{array}$ \\
\hline Zambezi & Evidence exist & Entire basin & Flood response plans & $\begin{array}{l}\text { Community } \\
\text { and state }\end{array}$ & $\begin{array}{l}\text { Catchment-wide } \\
\text { management and } \\
\text { livelihoods }\end{array}$ & $\begin{array}{l}\text { Expand on } \\
\text { catchment } \\
\text { management } \\
\text { program for policy }\end{array}$ \\
\hline Tana & Related evidence & $\begin{array}{l}\text { Wetland } \\
\text { resource use }\end{array}$ & Conservation & $\begin{array}{l}\text { International, } \\
\text { state }\end{array}$ & $\begin{array}{l}\text { Conservation with } \\
\text { adaptation co- } \\
\text { benefits }\end{array}$ & $\begin{array}{l}\text { Expand conservation } \\
\text { activities to } \\
\text { adaptation policy }\end{array}$ \\
\hline Rufiji & Related evidence & Water sector & Water allocation system & Regional & $\begin{array}{l}\text { Catchment-wide } \\
\text { management for } \\
\text { water resources }\end{array}$ & $\begin{array}{l}\text { Expand on } \\
\text { catchment } \\
\text { management } \\
\text { program for policy }\end{array}$ \\
\hline $\begin{array}{l}\text { Ganges- } \\
\text { Brahmaputra }\end{array}$ & Evidence & Integrated & $\begin{array}{l}\text { Micro to macro level } \\
\text { coastal management }\end{array}$ & $\begin{array}{l}\text { Community to } \\
\text { state }\end{array}$ & $\begin{array}{l}\text { Coastal } \\
\text { management } \\
\text { policy }\end{array}$ & $\begin{array}{l}\text { Mainstream } \\
\text { transformational } \\
\text { adaptation }\end{array}$ \\
\hline Okavango & Related & $\begin{array}{r}\text { Agricultural } \\
\text { and Water }\end{array}$ & $\begin{array}{l}\text { Livelihoods, tourism } \\
\text { and water } \\
\text { management }\end{array}$ & $\begin{array}{l}\text { Communities } \\
\text { and state } \\
\text { agency }\end{array}$ & $\begin{array}{l}\text { Conservation and } \\
\text { livelihoods }\end{array}$ & $\begin{array}{l}\text { Expand conservation } \\
\text { co-benefits and } \\
\text { mainstream for } \\
\text { policy }\end{array}$ \\
\hline Niger & Evidence & Integrated & $\begin{array}{l}\text { Flood control and } \\
\text { agriculture }\end{array}$ & $\begin{array}{l}\text { State and } \\
\text { communities }\end{array}$ & $\begin{array}{l}\text { Coastal } \\
\text { management } \\
\text { policy }\end{array}$ & $\begin{array}{l}\text { Mainstream } \\
\text { transformational } \\
\text { adaptation }\end{array}$ \\
\hline Pungue & $\begin{array}{l}\text { No evidence } \\
\text { despite threats of } \\
\text { salinity intrusion }\end{array}$ & Conservation & $\begin{array}{l}\text { Conservation for } \\
\text { tourism }\end{array}$ & $\begin{array}{l}\text { Local resource } \\
\text { utilization }\end{array}$ & Master Plan & $\begin{array}{l}\text { Mainstream } \\
\text { adaptation into } \\
\text { plan }\end{array}$ \\
\hline
\end{tabular}


Table 2 continued

\begin{tabular}{|c|c|c|c|c|c|c|}
\hline \multirow[t]{2}{*}{ Delta } & \multirow{2}{*}{$\begin{array}{l}\text { Example of existing } \\
\text { generic policy }\end{array}$} & \multirow{2}{*}{$\begin{array}{l}\text { Geographic } \\
\text { scope }\end{array}$} & \multirow{2}{*}{$\begin{array}{l}\text { Thematic focus of } \\
\text { implementation }\end{array}$} & \multirow{2}{*}{$\begin{array}{l}\text { Actors in } \\
\text { adaptation }\end{array}$} & \multicolumn{2}{|l|}{ Policy gaps } \\
\hline & & & & & $\begin{array}{l}\text { Evidence of } \\
\text { existing } \\
\text { adaptation } \\
\text { policy** }\end{array}$ & $\begin{array}{l}\text { Policy for } \\
\text { enhancement }\end{array}$ \\
\hline Betsiboka & Conservation & $\begin{array}{l}\text { Integrated } \\
\text { conservation } \\
\text { and tourism }\end{array}$ & Eco-tourism promotion & Government & $\begin{array}{l}\text { Water } \\
\text { management } \\
\text { projects }\end{array}$ & $\begin{array}{c}\text { Expand water } \\
\text { projects and } \\
\text { mainstream } \\
\text { adaptation }\end{array}$ \\
\hline
\end{tabular}

** Evidence is assessed based on reviewed literature and official project websites

*** Associated with limited access to French published literature

interventions. It emerges that current adaptation in the deltas is incremental, based on experiential knowledge and of short to medium term in its focus (Kates et al. 2012). The research gap is on how transformative adaptation would be developed and what shape it would take in view of local contexts. Emerging policy issues include (O'Brien 2012; Pelling et al. 2012):

- Risk interpretation is the basis of action by different actors. Evidence of policy indicates that the root causes of climate risks are not adequately addressed.

- There is existence of adaptation-targeted policy in some of the deltas but with mixed responses and levels of entry. These levels range from household to delta-wide initiatives with diverse actors.

- There is the evidence of development policies that are not adaptation-targeted. But this is inadequate to address long-term anticipated climate-related impacts.

- Evidence of a one-size-fits-all approach for coastal and delta regions and the key gap are in relation to localespecific adaptation that combines top-down with bottom-up approaches based on learning by doing in relation to long-term adaptation.

- Knowledge bases on adaptation practices have emerged recently, which is positive but there are issues of uptake at policy level for scaling up, which is critical for deltawide adaptation.

- There is evidence of the literature that delves into adaptation policy but presenting it as an end part of the process of risk assessment where other agencies will have to respond. This reinforces the insufficiency of knowledge about the risks, adaptation needs and adaptation planning.

- The "adaptation gap" which can be framed as the difference between the needed development in current terms and the additional development or adaptation that will be required to deal with future climate risks.

From the foregoing discussion, it is clear that knowledge will play a significant role but is currently insufficient to enable understanding adaptation policy and practice. Although not framed as a basis for future research, key issues that would inform future engagement in adaptation policy are summarized here. Adaptation follows knowledge about risks and literature exists that systematically identifies and characterizes vulnerabilities, but issues still exist of: (a) the methodologies and approaches appropriate for understanding social vulnerability at various scales in context of adaptation policy, (b) the role of unit of exposure, actors in adaptation and policies for future adaptation, (c) options around adaptation strategies that are not land based, (d) pathways required for adaptation policy and response in the deltas that transcend development, (e) the lessons from established/implemented policy and how practice can build on these lessons in the deltas, (f) lessons from regional experiences around responses to disasters and climate change risks. These issues are formulated not to be conclusive but rather form a broad basis for additional or even new formulations when engaging with adaptation in deltas.

\section{Conclusion}

The vulnerability of large river deltas to climate change is conditioned by several factors including, but not limited to, high population densities, resource endowment and extraction activities, infrastructure development and low coastal elevation. Deltas have had longstanding challenge of disasters on which the current literature focuses, but research on adaptation in deltas, while increasing, such literature remains inadequate. In this study, a mix of adaptation plans and strategies are documented to be taking place in river deltas in Africa and South Asia at both the national and local level. Current adaptation is predominantly focused on intra-delta vulnerabilities with local specific adaptation actions. This is also biased toward development sectors and not integrated from household to community levels though a multitude of agencies are 
involved in building resilience at the community level. However, these efforts are not properly mainstreamed in national-level policies for resilience building and transformational adaptation. The review shows that adaptation policy gaps exist surrounding knowledge advancement, scaling up actions, the "adaptation gap" and the move from incremental adaptation to transformational adaptation.

Open Access This article is distributed under the terms of the Creative Commons Attribution License which permits any use, distribution, and reproduction in any medium, provided the original author(s) and the source are credited.

\section{References}

Adekola O, Mitchell G (2011) The Niger Delta wetlands; threats to ecosystem services, their importance to dependent communities and possible management measures. Int J Biodiv Sci Ecosyst Ser Manag 7:50-68. doi:10.1080/21513732.2011.603138

Allen KM (2006) Community-based disaster preparedness and climate adaptation: local capacity-building in the Philippines. Disasters 30:81-101

Anbumozhi V, Breiling M, Pathmarajah S, Reddy VR (2012) Climate change in Asia and the Pacific: how can countries adapt? $400 \mathrm{pp}$

Aromar R (2008) Climate change risk: an adaptation and mitigation agenda for Indian cities. Environ Urban 20:207-229. doi:10. $1177 / 0956247808089157$

Asian Development Bank (2009) The economics of climate change in Southeast Asia: a regional review. Asian Development Bank, Manila

Auld H (2008) Disaster risk reduction under current and changing climate conditions. WMO Bull 57:118-125

Berrang-Ford L, Ford JD, Paterson J (2011) Are we adapting to climate change? Glob Environ Change 21:25-33. doi:10.1016/j. gloenvcha.2010.09.012

Berrang-Ford L, Pearce T, Ford JD (this issue) Systematic review approaches for climate change adaptation research. Reg Environ Change

Bhattacharya S (2010) Key vulnerabilities of human society in South Asia to climate change and adaptation issues and strategies. In: Mitra AP, Sharma C (eds), Global Environmental Changes in South Asia. Springer Netherlands, Dordrecht, pp. 327-349. doi:10.1007/978-1-4020-9913-7_11

Black R, Bennett SRG, Thomas SM, Beddington JR (2011) Climate change: migration as adaptation. Nature 478:447-449. http:// www.nature.com/nature/journal/v478/n7370/full/478477a.html

Brauch HG (2012) Policy responses to climate change in the mediterranean and MENA region during the anthropocene. In: Scheffran J, Brzoska M, Brauch HG, Link PM, Schilling J (eds), Climate change, human security and violent conflict. Springer Berlin Heidelberg, Berlin, Heidelberg, pp 719-794. http://www. springerlink.com/index/10.1007/978-3-642-28626-1_37

Bunce M, Brown K, Rosendo S (2010) Policy misfits, climate change and cross-scale vulnerability in coastal Africa: how development projects undermine resilience. Environ Sci Policy 13:485-497

Cameron TA, Saif R, Duquette E (2011) Extreme weather events and rural-to-urban migration. University of Oregon, p 35

Commission Niger Delta Development (2006) Niger Delta regional development master plan. NDDC, Port Harcourt p 218

De Souza K, Kituyi E, Leoen M, Harvey B, Murali KS, Ford J (this issue) Vulnerability to climate change in three hot spots in Africa and Asia: key issues for policy-relevant and resilience-building research. Reg Environ Change

Eadson W (2011) Adapting cities to climate change understanding and addressing the development challenges. Int Plan Stud 16:191-194

Eisenack K, Stecker R (2012) A framework for analyzing climate change adaptations as actions. Mitig Adapt Strateg Glob Change 17:243-260. doi:10.1007/s11027-011-9323-9

El-Raey M (1997) Vulnerability assessment of the coastal zone of the Nile delta of Egypt, to the impacts of sea level rise. Ocean Coast Manag 37:29-40

Ezekiel E, Abowei J, Charles E (2013) Effects of flooding on Amassoma flood plain sediments Niger delta. Appl Sci Rep 4(1):173-180

Ford JD, Berrang-Ford L, Paterson J (2011) A systematic review of observed climate change adaptation in developed nations. Clim Change 106:327-336

Ford JD, Berrang-Ford L, Bunce A, Mckay C, Irwin M, Pearce T (this issue) The current status of climate change adaptation policy in Africa and Asia. Reg Environ Change

Fuchs R (2010) Cities at risk: Asia's coastal cities in an age of climate change. Asia Pacific Issues Series; no. 96, HI East-West Center, p 12

Fünfgeld H, Millin S, McEvoy D (2012) The adaptation navigator. RMIT University, $\mathrm{p} 23$

Gaillard J, Mercer J (2013) From knowledge to action bridging gaps in disaster risk reduction. Prog Hum Geogr 37:93-114

Ghile Y, Taner M, Brown C, Grijsen J, Talbi A (2014) Bottom-up climate risk assessment of infrastructure investment in the Niger River Basin. Clim Change 122:97-110

Haasnoot M, Kwakkel JH, Walker WE, ter Maat J (2013) Dynamic adaptive policy pathways: a method for crafting robust decisions for a deeply uncertain world. Glob Environ Change 23:485-498

Haig MR (2010) The indus delta country. Walton Press, Walton

Hinkel J, Brown S, Exner L, Nicholls RJ, Vafeidis AT, Kebede AS (2012) Sea-level rise impacts on Africa and the effects of mitigation and adaptation: an application of DIVA. Reg Environ Change 12:207-224. doi:10.1007/s10113-011-0249-2

Hugo GJ (2013) Migration and climate change. Edward Elgar Publishing, Camberley

Hyder AA, Corluka A, Winch PJ, El-Shinnawy A, Ghassany H, Malekafzali H, Lim M-K, Mfutso-Bengo J, Segura E, Ghaffar A (2010) National policy-makers speak out: are researchers giving them what they need? Health Policy Plan 26:73-82

IPCC (2014a) Summary for policymakers. In: Climate change 2014: impacts, adaptation, and vulnerability. Part A: global and sectoral aspects. Contribution of Working Group II to the Fifth Assessment Report of the Intergovernmental Panel on Climate Change, Field CB, Barros VR, Dokken DJ, Mach KJ, Mastrandrea MD, Bilir TE, Chatterjee M, Ebi KL, Estrada YO, Genova RC, Girma B, Kissel ES, Levy AN, MacCracken S, Mastrandrea PR, White LL (eds) Cambridge University Press, Cambridge, UK, New York, NY, USA, p 1-32

IPCC (2014b) Chapter 5 coastal systems and low-lying areas: contribution of the Working Group II to the Fifth Assessment Report of the Intergovernmental Panel on Climate Change (Fifth Assessment Report 5AR). In: Nicholls R, Santos F (eds) IPCC Assessment Reports. p 85

Islam MR (2006) 18 Managing diverse land uses in coastal Bangladesh: Institutional approaches. Environment and livelihoods in tropical coastal zones, p 309

ISSC, UNESCO (2013) World social science report 2013: changing global environments. OECD Publishing and UNESCO, Paris 30p

Kates RW, Travis WR, Wilbanks TJ (2012) Transformational adaptation when incremental adaptations to climate change are insufficient. Proc Natl Acad Sci 109:7156-7161. doi:10.1073/ pnas. 1115521109 
Kilroy G (2014) A review of the biophysical impacts of climate change in three hotspot regions in Africa and Asia. Reg Environ Change. doi:10.1007/s10113-014-0709-6

Lebel L, Nikitina E, Pahl-Wostl C, Knieper C (2013) Institutional Fit and River Basin Governance: a new approach using multiple composite measures. Ecol Soc 18(1). Article no. 1

Lee T, van de Meene S (2012) Who teaches and who learns? Policy learning through the $\mathrm{C} 40$ cities climate network. Policy Sci 45:199-220

Marcus M (2010) Responding to climate and other change processes in complex contexts: challenges facing development of adaptive policy frameworks in the Ganga Basin. Technol Forecast Soc Chang 77:975-986

Ministry of Energy and Forestry (2008) Bangladesh climate change strategy and action plan 2008. 104p

Moors EJ, Groot A, Biemans H, van Scheltinga CT, Siderius C, Stoffel M, Huggel C, Wiltshire A, Mathison C, Ridley J, Jacob D, Kumar P, Bhadwal S, Gosain A, Collins DN (2011) Adaptation to changing water resources in the Ganges basin, northern India. Environ Sci Policy 14:758-769. http://www. sciencedirect.com/science/article/pii/S1462901111000372

Motsholapheko MR, Kgathi DL, Vanderpost C (2011) Rural livelihoods and household adaptation to extreme flooding in the Okavango Delta, Botswana. Phys Chem Earth Parts A/B/C 36(14-15):984-995

Nishat A, Mukherjee N, Hasemann A, Roberts E (2013) Loss and damage from the local perspective in the context of a slow onset process. Cent Clim Change Environ Res p 20

O’Brien K (2012) Global environmental change II from adaptation to deliberate transformation. Prog Hum Geogr 36:667-676

Ole M, Kirsten H, Jørgen E, Kjeld R (2009) Adaptation to climate change in developing countries. Environ Manage 43:743-752

Olobaniyi SB, Owoyemi FB (2010) Characterization by factor analysis of the chemical facies of groundwater in the deltaic plain sands aquifer of Warri, western Niger delta, Nigeria. Afr J Sci Technol 7: (1), http://www.ajol.info/index.php/ajst/article/ view/55201

Pelling M, Blackburn S (2014) Megacities and the coast: risk, resilience and transformation. Routledge, p 200

Pelling M, Manuel-Navarrete D, Redclift M (2012) Climate change and the crisis of capitalism: a chance to reclaim, self, society and nature. Routledge, p 213, ISBN 9781136507670

Rabbani G, Rahman A, Mainuddin K (2013) Salinity-induced loss and damage to farming households in coastal Bangladesh. Int $\mathrm{J}$ Glob Warm 5(4):400-413. doi:10.1504/IJGW.2013.057284

Rao P (2013) Building climate resilience in coastal ecosystems in India: cases and trends in adaptation practices. In: Leal Filho W (ed), Climate change and disaster risk management. Springer, Berlin, Heidelberg, pp 335-349
Rawlani AK, Sovacool BK (2011) Building responsiveness to climate change through community based adaptation in Bangladesh. Mitig Adapt Strat Glob Change 16:845-863

Saito N (2013) Mainstreaming climate change adaptation in least developed countries in South and Southeast Asia. Mitig Adapt Strat Glob Change 18:825-849

Sarwar GM, Khan MH (2007) Sea level rise. Int Asien Forum 38:375-397

Sharma V, Hugo G (2010a) Climate change implications on human livelihoods and security: lessons from the Ganges-Brahmaputra and the Mekong delta regions in Asia. Conference paper at the 1st Asian population association conference 16-20 Nov 2010, New Delhi

Smith B, Burton I, Klein RJT, Wandel J (2000) An anatomy of adaptation to climate change and variability. Clim Change $45: 223-251$

Speranza CI (2010) Flood disaster risk management and humanitarian interventions in the Zambezi River Basin: implications for adaptation to climate change. Clim Dev 2: 176-190. http://www. tandfonline.com/doi/abs/10.3763/cdev.2010.0041

Steve T, Francis T, Moses M, Robert D, Durton N, Peter C, Mark H (2008) Building adaptive capacity to cope with increasing vulnerability due to climatic change in Africa: A new approach. Phys Chem Earth, 780-787

Syvitski JPM, Kettner AJ, Overeem I, Hutton EWH, Hannon MT, Brakenridge GR, Day J, Vörösmarty C, Saito Y, Giosan L, Nicholls RJ (2009) Sinking deltas due to human activities. Nat Geosci 2:681-686. http://www.nature.com/doifinder/10.1038/ ngeo629

Tucker J, Few R, Conway D, Daoud M, Oates N, Mtisi S, Matheson S (this issue) Social vulnerability in three high poverty climate change hotspots: what does the climate literature tell us? Reg Environ Change

UNFCCC (2007) Climatic change impact, vulnerabilities and adaptation in developing countries. UNFCCC Secretariat, Bonn, Germany, p 68. http://unfccc.int/resource/docs/publications/ impacts.pdf

UNFCCC (2012) Slow onset events technical paper (Technical Report No. GE.12-70822). United Nations Framework Convention on Climate Change, Geneva, Switzerland, p 61

Wassmann R, Jagadish S, Sumfleth K, Pathak H, Howell G, Ismail A, Serraj R, Redona E, Singh R, Heuer S (2009) Regional vulnerability of climate change impacts on Asian rice production and scope for adaptation. Adv Agron 102:91-133. doi:10.1016/ S0065-2113(09)01003-7

Woodworth P, Aman A, Aarup T (2007) Sea level monitoring in Africa. Afr J Mar Sci 29:321-330. doi:10.2989/AJMS.2007.29.3. 2.332 